\title{
Urindyppekultur i allmennpraksis
}

\begin{abstract}
Sammendrag
Bakgrunn. På et strategimøte ved Nasjonalt folkehelseinstitutt ble det vedtatt å sette ned grenseverdien for hva som regnes som signifikant bakteriuri ved mikrobiologiske laboratorier fra $10^{4}$ til $10^{3}$ kolonidannende enheter per milliliter (cfu/ml). En så lav verdi er vanskelig å avlese på urindyppekultur, og NOKLUS' referansegruppe i mikrobiologi ønsket derfor å foreta en litteraturgjennomgang av bruken av dyppekulturer i allmennpraksis.
\end{abstract}

\section{Materiale og metode. Artikkelen er basert på et ikke-systematisk søk i PubMed og forfatternes erfaring og forskning innen feltet.}

Resultater. Escherichia coli er vanligste agens ved både nedre og øvre urinveisinfeksjoner og ved asymptomatisk bakteriuri hos gravide. Ved de fleste infeksjoner, særlig ved øvre urinveisinfeksjoner, er bakteriekonsentrasjonen minst $10^{4}$ kolonidannende enheter per milliliter urin i renkultur. Dyppekultur bør foretrekkes som transportmedium ved transporttid over to døgn fordi antallet bakteriekolonier ikke påvirkes, ellers foretrekkes urin tilsatt borsyre.

Fortolkning. Dyppekultur med E coliagar kan gi viktig informasjon ved kompliserte (særlig øvre) urinveisinfeksjoner og ved undersøkelse for asymptomatisk bakteriuri hos gravide. Dyppekultur skal ikke brukes ved ukomplisert cystitt. Der man velger å bruke dyppekultur, må legekontoret oppnå og vedlikeholde tilstrekkelig kompetanse og delta på NOKLUSutsendelsene. Korrekt prøvetaking og håndtering av urinprøver er enda viktigere enn det var tidligere på grunn av lavere grenseverdi for signifikant bakteriuri.

\section{Geir Thue}

geir.thue@isf.uib.no

NOKLUS

Postboks 6165

5892 Bergen

og

Seksjon for allmennmedisin

Institutt for samfunnsmedisinske fag

Universitetet i Bergen

\section{Anders Bærheim}

Seksjon for allmennmedisin

Institutt for samfunnsmedisinske fag

Universitetet i Bergen

\section{Wenche Iren Bjelkarøy}

NOKLUS

\section{Asbjørn Digranes}

Nedre Smøråsveg 45

5238 Rådal

Urindyppekultur ble introdusert i Norge tidlig i 1970-årene og har fått betydelig anvendelse ved bakteriologisk diagnostikk av urinveisinfeksjoner i allmennpraksis. Norsk kvalitetsforbedring av laboratorievirksomhet utenfor sykehus (NOKLUS) har årlig utsendelser av dyppekulturer til ca. 750 legekontorer der man vurderer og tolker veksten - det vil si at halvparten av legekontorene her i landet har dyppekultur på laboratorierepertoaret. De bruker den 11 ganger per uke per legekontor i gjennomsnitt (upubliserte egne data).

Ved hjelp av dyppekultur kan bakterikonsentrasjonen i urinen bestemmes. Dyppekultur kan også benyttes som transportmedium når sikker identifikasjon og resistensbestemmelse av bakteriene ønskes. Den kan imidlertid være vanskelig å tolke, særlig når bakteriekonsentrasjonen i urinen er lavere enn $10^{4}$ kolonidannende enheter per milliliter urin (cfu/ml), som lenge har vært grenseverdien for såkalt signifikant bakteriuri.

Fordi norske mikrobiologiske laboratorier etter et strategimøte ved Nasjonalt folkehelseinstitutt vil ta i bruk grenseverdier ned i $10^{3} \mathrm{cfu} / \mathrm{ml}$, ønsket medlemmer av referansegruppen i mikrobiologi ved NOKLUS å diskutere bruk og nytte av dyppekultur i allmennpraksis. Vi gir en omtale av noen kliniske og bakteriologiske forhold ved urinveisinfeksjoner, omtaler de nye grenseverdiene, beskriver ulike varianter av dyppekultur og kommer med anbefalinger for bruken av dem i allmennpraksis.

\section{Materiale og metode}

Artikkelen er basert på et ikke-systematisk søk i PubMed. Det er gjort et skjønnsomt utvalg av artikler ut fra forfatternes erfaringer og forskning innen feltet.

\section{Kliniske og bakteriologiske forhold ved urinveisinfeksjoner}

Urinveisinfeksjon er bakgrunn for 3-4\% av pasientkontaktene i allmennpraksis (1). «Ukomplisert cystitt» er definert som cystitt hos en ellers frisk, ikke-gravid kvinne $i$ alderen 15-55 år med normale urinveier (2). Også eldre og yngre kvinner har ofte ukomplisert cystitt, selv om definisjonen ikke dekker disse aldersgruppene. Tilstanden gir nesten alltid typiske symptomer (pollakisuri, dysuri og suprapubiske smerter) og kan behandles uten videre undersøkelser (1). Bakteriologisk undersøkelse av urinen er bare nødvendig dersom kvinnen ikke blir bra innen en uke eller raskt får en ny infeksjon, eller dersom diagnosen er usikker pga. vage eller ukarakteristiske symptomer (1). Ukomplisert cystitt forårsakes i ca. $80 \%$ av tilfellene av Escherichia coli, ellers oftest av Staphylococcus saprophyticus (3).

Alle andre urinveisinfeksjoner enn cystitt hos friske kvinner er per definisjon kompliserte, og det anbefales å utføre bakteriologisk undersøkelse med resistensbestemmelse (4) (ramme 1). Forekomsten av slike infeksjoner er langt lavere enn forekomsten av ukomplisert cystitt, for eksempel er forholdet mellom urinveisinfeksjoner hos kvinner og menn i alderen 20-60 år 100:1. Pyelonefritt (øvre urinveisinfeksjon) er også sjeldent, insidensraten anslås til én av 1000 personer per år i USA (5). To tredeler av disse forekommer hos ellers friske, og de

\section{Hovedbudskap}

- Grenseverdien for signifikant bakteriuri settes ned. Dette påvirker bruken av urindyppekultur

- Urindyppekultur kan brukes ved kompliserte urinveisinfeksjoner og ved undersøkelse for asymptomatisk bakteriuri hos gravide. Den skal ikke brukes ved ukomplisert cystitt

- Dyppekultur er egnet som transportmedium ved lang transporttid til laboratoriet

- Bruk av dyppekultur krever tilstrekkelig kompetanse og deltakelse på NOKLUSutsendelsene 


\section{Ramme 1}

\section{Indikasjoner for bakteriologisk undersøkelse av urin (4). Slik undersøkelse er ikke indisert ved ukomplisert cystitt}

\section{$\emptyset$ vre urinveisinfeksjoner}

Ved terapisvikt

Urinveisinfeksjoner som oppstår under pågående profylakse

Urinveisinfeksjoner hos barn

Urinveisinfeksjoner hos menn

Urinveisinfeksjoner hos gravide

Urinveisinfeksjoner hos personer med diabetes mellitus

Urinveisinfeksjoner ervervet i sykehus

Urinveisinfeksjoner etter instrumentering av urinveiene

Urinveisinfeksjoner hos pasienter med stenose i urinveiene

Urinveisinfeksjoner hos pasienter med urolithiasis

- Urinveisinfeksjoner hos en del eldre og andre pasienter med nedsatt infeksjonsforsvar

- Urinveisinfeksjoner hos pasienter med innlagt kateter

\section{Ramme 2}

\section{Inndeling av urinveispatogene mikroorganismer med grenseverdier for signifikant bakteriuri}

Primærpatogene arter, grenseverdi $10^{3}$ cfu/ml (gir infeksjoner hos personer med normale urinveier)

Escherichia coli

Staphylococcus saprophyticus ${ }^{1}$

Sekundærpatogene arter, grenseverdi $10^{3} \mathrm{cfu} / \mathrm{ml}$ lgir infeksjoner hos disponerte pasienter)

Klebsiella

Proteus

Enterobacter

Citrobacter

Enterokokker ${ }^{1}$

Pseudomonas aeruginosa

Staphylococcus aureus ${ }^{1}$

Tvilsomt patogene arter, grenseverdi $10^{4}$ cfu/ml for barn; $10^{5} \mathrm{cfu} / \mathrm{ml}$ for voksne Igir trolig infeksjoner hos enkelte disponerte pasienter)

Gruppe B-streptokokker ${ }^{1}$

Hvite stafylokokker ${ }^{1}$

(andre enn S saprohyticus)

Acinetobacter

Pseudomonas-arter

(andre enn $P$ aeruginosa)

Candida

1 Grampositive bakterier fleste kan behandles utenfor sykehus. Symptomene er ofte typiske, og urinstrimmelfunn og forhøyet nivå av C-reaktivt protein er til god hjelp i diagnostikken (6). Urinstrimmel med betydelig utslag på leukocytter, men negativ på nitritt, tyder på infeksjon med en grampositiv bakterie.

Bleiebarn representerer en spesiell utfordring. De bør ofte innlegges for å sikre diagnosen der det er mistanke om urinveisinfeksjon. Negativ poseprøve kan brukes til å avkrefte dette, en positiv må følges opp med blærepunksjon eller kateterprøve (7). Hos større barn er diagnostikken av urinveisinfeksjon som hos voksne. Prøvetaking hos sengeliggende eldre kan gjøres ved kateterisering, som er en minst like god metode som midtstråleurin. E coli dominerer også ved kompliserte urinveisinfeksjoner, både øvre og nedre, mens forekomsten av S saprophyticus og andre bakteriearter er varierende.

Det er ikke nødvendigvis noen sammenheng mellom bakteriekonsentrasjonen i urinen og pasientens symptomer. Hos ubehandlede kvinner kan imidlertid konsentrasjonen øke utover i infeksjonsforløpet, og den er ofte høyere ved øvre urinveisinfeksjoner (ikke sjelden $\geq 10^{5} \mathrm{cfu} / \mathrm{ml}$ ) enn ved cystitt (8). I de fleste tilfeller av cystitt er konsentrasjonen minst $10^{4} \mathrm{cfu} / \mathrm{ml}$. Lavere konsentrasjoner forekommer, men det er usikkert hvor ofte dette er tilfellet (8). Det foreligger ikke studier om sammenhengen mellom bakteriekonsentrasjon og symptomer på urinveisinfeksjon hos menn og barn.

Asymptomatisk bakteriuri, det vil si funn av $\geq 10^{5} \mathrm{cfu} / \mathrm{ml}$ med samme bakteriestamme (oftest E coli) i to påfølgende prøver hos asymptomatiske individer, har bare konsekvenser hos gravide og hos barn under fire år med kjent vesikoureteral refluks (1). Forekomsten av urinveisinfeksjoner hos gravide er usikker, men antas å ligge på rundt $2-5 \%$ i land som Norge (9). Det foreligger ikke studier som tilsier at grenseverdien på $\geq 10^{5}$ $\mathrm{cfu} / \mathrm{ml}$ bør settes ned. Nytteverdien av å screene gravide er omdiskutert. Screening er ikke anbefalt $\mathrm{i}$ gjeldende retningslinjer for svangerskapsomsorgen (10), men i de nye retningslinjene for antibiotikabruk i primærhelsetjenesten anbefales det (6). Det må uansett være viktig å undersøke på asymptomatisk bakteriuri hos gravide som har hatt uvanlig mange urinveisinfeksjoner tidligere eller har hatt øvre urinveisinfeksjon.

\section{Nye grenseverdier for bakteriuri}

Bakteriologisk diagnostikk ved urinveisinfeksjon ble i mange år basert på påvisning av «signifikant bakteriuri», dvs. funn av $\geq 10^{5}$ $\mathrm{cfu} / \mathrm{ml}$. Dette begrepet, som ble introdusert av Edward Kass i midten av 1950-årene (11), fikk stor betydning for det å skille mellom bakteriuri og bakterier som skyldtes forurensning ved prøvetakingen. I 1980-årene ble det imidlertid publisert en rekke studier som viste at det hos kvinner med urinveisinfeksjon ikke sjelden var betydelig lavere bakteriekonsentrasjoner, og fra 1993 er det i Norge blitt benyttet en grenseverdi på $10^{4} \mathrm{cfu} / \mathrm{ml}$ urin som kriterium for signifikant, ofte behandlingstrengende bakteriuri (12). Senere undersøkelser av bakteriekonsentrasjoner ved urinveisinfeksjon har vist at også denne grenseverdien var for høy (8), og i 2000 ble det publisert nye europeiske retningslinjer (8). På et strategimøte ved Nasjonalt folkehelseinstitutt i november 2007 ble det vedtatt å innføre lavere grenseverdier også i Norge (13). For de vanligste bakterieartene ble grenseverdien redusert til $10^{3} \mathrm{cfu} / \mathrm{ml}$ (ramme 2). Dette innebærer at det må stilles store krav til prøvetaking, behandling av prøvene, transport og bakteriologisk undersøkelse av urinen.

Midtstråleurin plassert i kjøleskap like etter prøvetaking anbefales. Urinprøven bør leveres til legekontoret og klargjøres for dyrking innen to timer for å unngå at bakterier i prøven får tid til å formere seg. Dersom prøven ikke er optimal, er det bedre å ta en ny prøve på legekontoret. Blæreinkubering (minst to timer siden siste urinlating) betyr mindre og kan være umulig å oppnå ved hissige cystitter på grunn av meget hyppig vannlating.

\section{Dyppekulturer}

Ved legekontorene bruker man nå tre varianter av dyppekultur: DipSlide (Novamed Ltd, Israel), Uricult og Uricult Trio (Orion Diagnostica Oy, Espoo, Finland). Orion har en markedsandel på over $95 \%$, og Uricult Trio brukes ved de aller fleste legekontorer fordi firmaet har besluttet å erstatte vanlig Uricult med Uricult Trio.

På DipSlide og Uricult finnes to dyrkingsmedier (CLED- og MacConkey-agar), på Uricult Trio i tillegg en såkalt E coli-agar. På CLED-agar vokser alle de vanlige urinveispatogene bakteriene, både grampositive og gramnegative, mens det på MacConkeyagaren nesten bare vokser gramnegative stavbakterier som E coli, andre enterobakterier og pseudomonasarter. Grampositive bakterier vokser ikke, eller bare med svært små kolonier. På E coli-agar vokser de samme bakterieartene som på MacConkey-agar, men på dette mediet blir E coli-koloniene svarte eller brunsvarte. Fargen skyldes at E coli, i motsetning til de fleste andre gramnegative stavbakterier, produserer et enzym (betaglukuronidase) som spalter et substrat som er tilsatt mediet.

Ved å inkubere dyppekulturene (16-24 t ved $35-37^{\circ} \mathrm{C}$ ) og vurdere bakterieveksten kan legekontorene få viktig informasjon om (fig 1):

- Bakteriekonsentrasjonen i urinen. Den kvantitative vurderingen skal foretas bare på grunnlag av veksten på CLED-agar - Renkultur av bakterier eller blandingskultur? Blandingsinfeksjon i urinveiene er sjelden, og blandingskulturer (vekst av kolonier med forkjellig utseende) tyder derfor på at urinen er blitt forurenset 
- Gramnegative eller grampositive bakterier? Vekst både på CLED- og MacConkey-agar tyder på at infeksjonen skyldes en gramnegativ stavbakterie, vanligvis E coli. Vekst bare på CLED-agar tyder på at infeksjonen er forårsaket av en grampositiv bakterie (vanligvis S saprohyticus, som gir infeksjoner spesielt hos yngre kvinner, eller enterokokker)

- E coli-infeksjon? Svarte eller brunsvarte kolonier på E coli-agar viser med stor sannsynlighet at infeksjonen skyldes E coli

- Resistensbestemmelse må foretas ved mikrobiologisk laboratorium

De nye grenseverdiene for bakteriuri fører imidlertid til at den kvantitative vurderingen kan bli problematisk. Mens bakteriekonsentrasjoner på $10^{4} \mathrm{cfu} / \mathrm{ml}$ gir ca. 100 kolonier på CLED-siden på dyppekulturen, gir $10^{3}$ $\mathrm{cfu} / \mathrm{ml}$ vekst av bare omtrent ti kolonier. Ved vekst av så få kolonier er det vanskelig å avgjøre om bakteriene er uttrykk for reell bakteriuri eller om de skyldes forurensning. Dyppekulturer med så sparsom vekst må dessuten sendes til mikrobiologisk laboratorium for å få avklart om bakteriene tilhører primær- eller sekundærpatogene arter eller ikke (ramme 2). Det er for øvrig viktig å være klar over at noen urinveispatogene bakterier ikke vokser ved vanlig romtemperatur, slik at inkubering av dyppekulturen i romtemperatur «over helgen» kan gi falskt negativt resultat.

En fordel med dyppekulturene er at den kvantitative vurderingen ikke blir påvirket av flere døgns transport, fordi én bakterie gir opphav til én koloni. Hvis dyppekulturene inkuberes ved legekontorene og bare kulturer med bakterievekst sendes inn, vil laboratoriene dessuten bli spart for mange negative prøver. På den annen side er blandingskulturer vanskelige å vurdere på dyppekultur, og det kan være umulig å bestemme mengdeforholdet mellom de ulike bakterieartene og avgjøre hvilken som dominerer og kan tillegges betydning. Enkelte laboratorier foretrekker derfor at urinprøver sendes inn på borsyreglass uansett. Med transporttid over to døgn, f.eks. ved innsending før helger, kan antallet bakterier i prøven imidlertid bli redusert og føre til falskt negativt resultat. Dette blir et større problem dersom bakteriekonsentrasjonen i utgangspunktet er lav. I slike situasjoner bør dyppekultur benyttes som transportmedium fremfor urin tilsatt borsyre. Dyppekulturen kan også sendes uinkubert, men da må dette oppgis på rekvisisjonen.

I Sverige var dyppekultur inntil 2007 bare anbefalt til bruk ved førstegangsinfeksjon hos kvinner i fertil alder eller som kontroll etter avsluttet behandling. Nå anbefales ikke lenger bruk av dyppekultur i Sverige, regelen er at urinprøver sendes til mikrobiologisk laboratorium. Gjennomgang av data ved Extern kvalitetssäkring inom laborato- riemedicin i Sverige (EQUALIS) har vist at legekontorene har problemer med å avlese dyppekulturen korrekt - særlig gjelder det blandingskulturer med og uten E coli (14). Det legges også vekt på at innsending av urinprøver gir bedre mulighet for å følge resistensutviklingen.

Erfaringer fra NOKLUS-utsendelser av dyppekulturer (inkuberte dyppekulturer eller bilder av slike) viser at omtrent halvparten av legekontorene ikke utnytter den informasjonen dyppekulturen gir og at mange rutinemessig sender kulturene til mikrobiologisk laboratorium uten å ha vurdert veksten (15) Der man foretar fullstendig avlesning, gjør man det som oftest korrekt, spesielt der fasiten er renkultur med vekst på $10^{4}-10^{5} \mathrm{cfu} / \mathrm{ml}$. Ved legekontorer der man bruker dyppekultur sjeldnere, en det en tendens til noe lavere avlesningskvalitet.

\section{Når er det nyttig med rask diagnostikk av bakteriuri?}

Dyppekultur gir svar påfølgende dag, mens undersøkelse med resistensbestemmelse av prøver innsendt på borsyreglass vanligvis tar to døgn etter at prøven er mottatt i laboratoriet (ett døgn ved negative prøver). Hvis det er innført elektronisk svarrapportering eller hentetjeneste, vil allmennlegen få svaret samme dag som det foreligger. Men siden svaret ikke er klart i tilslutning til konsultasjonen, vil behandlingen uansett bli empirisk.

Ved ukompliserte urinveisinfeksjoner er effekten av empirisk behandling svært god (16) og skifte av behandling vil bare skje
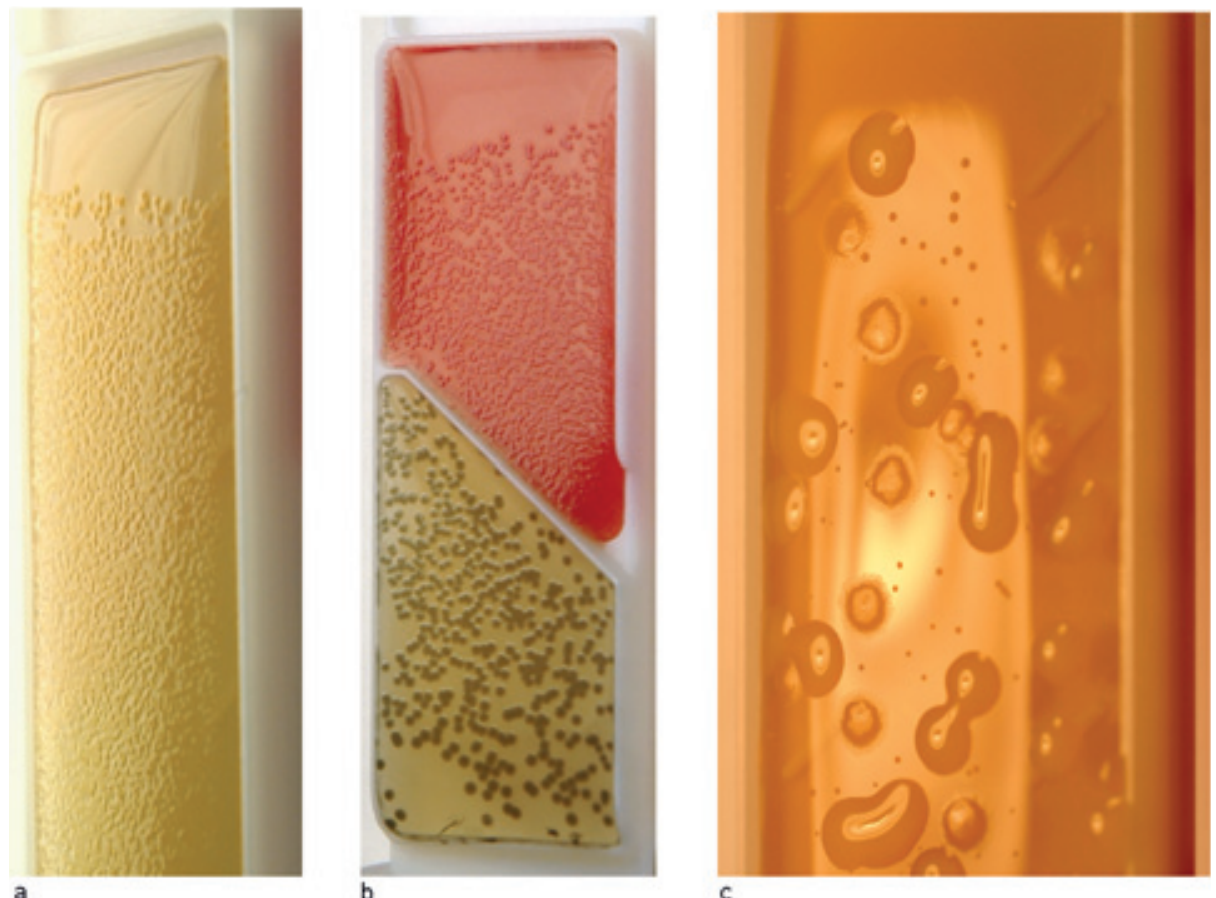

Figur 1 Eksempel på en inkubert urindyppekultur (Uricult Trio). Legg merke til at det skal gjenstå et «udyppet» felt øverst som brukes som referanse når veksten vurderes. al Rikelig vekst av bakterier i renkultur på CLED-agar og b) samtidig vekst på MacConkey-agar (rødlig) og E coli-agar tyder på E coli (brunsvarte kolonier). c) Blandingskultur på CLED-agar med både store og små kolonier, som det kan være lett å overse. Foto E.A. Høiby dersom pasienten ikke raskt blir bra, uansett I praksis betyr det derfor lite at bruk av dyppekultur gjør det mulig å justere behandlingen, for eksempel dersom det viser seg at infeksjonen skyldes en grampositiv bakterie (oftest S saprophyticus) og det er startet behandling med mecillinam. S saprophyticus er riktignok resistent mot mecillinam in vitro, men ofte ikke in vivo (17). Dyppekultur skal ikke brukes ved ukomplisert cystitt, og ved behandlingssvikt bør det sendes urin tilsatt borsyre til identifisering og resistensbestemmelse av bakteriene.

I en del tilfeller med dysuri der cystitt vurderes som mindre sannsynlig, eller ved vage cystittsymptomer, vil bruk av dyppekultur kunne spare innsending av sikkert positive prøver. Det vil ikke være mulig å stole på en negativ prøve, fordi bakteriekonsentrasjonen kan være lav og likevel signifikant. Også i slike tilfeller bør glass med borsyre foretrekkes om ikke transporttiden er for lang.

Ved kompliserte urinveisinfeksjoner (ramme 1), særlig ved øvre urinveisinfeksjoner som kan være utgangspunkt for urosepsis, har det større betydning å få bekreftet at det foreligger bakteriuri i løpet av det første døgnet etter påbegynt behandling. Bakteriekonsentrasjonen vil da som regel være så høy at veksten på dyppekulturen kan vurderes uten problemer. Ved slike infeksjoner har det dessuten betydning å endre behandling så snart som mulig, eventuelt få en bekreftelse på at effektiv behandling sannsynligvis er valgt dersom $\mathrm{E}$ coli blir påvist. Alle dyppekulturer hva dyppekulturen måtte vise dagen etter. 
med bakterievekst (uansett konsentrasjon) sendes til mikrobiologisk laboratorium. Dersom pasienten har allmennsymptomer, bør det samtidig sendes urin tilsatt borsyre.

Ved undersøkelse for asymptomatisk bakteriuri hos gravide kan bruk av dyppekultur være aktuelt siden grenseverdien ved ved denne tilstanden er så høy som $10^{5} \mathrm{cfu} / \mathrm{ml}$. Bruk av dyppekultur for dette formålet krever jevnlig praksis og kvalitetskontroll, men vil spare de mikrobiologiske laboratoriene for et stort antall negative prøver. I en undersøkelse ved et legekontor var Uricult dårligere som screeningmetode for asymptomatisk bakteriuri enn innsending av urin tilsatt borsyre (18), mens resultatene fra flere NOKLUS-utsendelser viser at ved mer enn $80 \%$ av legekontorene som vurderer dyppekulturene, vurderer man renkultur med så høy bakteriekonsentrasjon korrekt (15).

\section{Konklusjoner og anbefalinger}

Ved kompliserte urinveisinfeksjoner, særlig øvre urinveisinfeksjon, kan dyppekultur brukes som ledd i diagnostikken og bidra til korrekt behandling. Dersom pasienten har allmennsymptomer, bør det samtidig sendes urin tilsatt borsyre. Dyppekultur kan også brukes ved undersøkelse for asymptomatisk bakteriuri hos gravide. Det er en fordel om dyppekulturen gir mulighet for å identifisere E coli. Bakteriologisk undersøkelse av urin er ikke indisert ved cystitt hos kvinner i fertil alder, unntatt ved behandlingssvikt, og da bør det sendes urin tilsatt borsyre. Ved transporttid over to døgn bør imidlertid dyppekultur brukes som transportmedium. Korrekt prøvetaking og håndtering av urinprøver er enda viktigere enn det var før - på grunn av lavere grenseverdi for signifikant bakteriuri.
Dersom bruken av dyppekultur reduseres vesentlig som følge av de nye grenseverdiene og mer målrettet bruk, kan det bli krevende å oppnå og vedlikeholde tilfredsstillende kompetanse. Deltakelse i NOKLUSutsendelsene til dyppekultur er nødvendig, og NOKLUS bør intensivere innsatsen for å sikre korrekt bruk av kulturen. Ved legekontorene må man på sin side vurdere den kliniske nytten av dyppekultur sett i forhold til innsatsen som kreves.

Oppgitte interessekonflikter: Wenche Iren Bjelkarøy og Asbjørn Digranes har mottat foredragshonorar fra Orion Diagnostica. De andre forfatterne har ingen oppgitte interessekonflikter.

Vi takker E. Arne Høiby ved Nasjonalt folkehelseinstitutt og Kjetil K. Melby ved Oslo universitets sykehus, Ullevål, for verdifulle kommentarer. De er, i likhet med forfatterne, medlemmer NOKLUS' referansegruppe i mikrobiologi. Vi takker også Nils Grude (Unilabs Telelab, Skien) for kommentarer og synspunkter.

\section{Litteratur}

1. Hunskår S, Bærheim A, Lærum E. Nyrer og urinveier. I: Hunskår S, red. Allmennmedisin. Oslo: Gyldendal, 2003: 547-81.

2. Skudal H. Urinveisinfeksjon - definisjon og klassifikasjon. I: Grude N, Hermansen NO, Leegaard T. Bakteriologisk diagnostikk ved urinveisinfeksjoner. Strategimøte nr. 21, 2007. Oslo: Nasjonalt folkehelseinstitutt, 2008: 16

3. Jureen R, Digranes A, Bærheim A. Urinveispatogene bakterier ved ukomplisert nedre urinveisinfeksjon hos kvinner. Tidsskr Nor Lægeforen 2003; 123: 2021-2.

4. von der Lippe E. Indikasjoner for bakteriologisk dyrkning ved urinveisinfeksjoner. I: Hovig B, assen J, Sandven P et al, red. Bakteriologisk diagnostikk ved urinveisinfeksjon. Konsensusrapport nr. 7, Oslo: Statens institutt for folkehelse, 1994: 14-9.
5. Hooton TM, Stamm WE. Diagnosis and treatment of uncomplicated urinary tract infection. Infect Dis Clin North Am 1997; 11: 551-81.

6. Nasjonale faglige retningslinjer for antibiotikabruk i primærhelsetjenesten. Oslo: Helsedirektoratet og Antibiotikasenteret for primærmedisin, 2008

7. Jenner R, Afzalnia S. Best evidence topic report Clean catch or bag specimen in UTI in non toilet trained children? Emerg Med J 2006; 23: 219-20.

8. Kouri T, Fogazzi G, Gant V et al. European urinalysis guidelines: summary. Scand J Clin Lab Invest Suppl 2000; 60 (suppl 231): 1-96.

9. Aadland G, Backe B, Hunskår S et al. Svangerskap, fødsel og familieplanlegging. I: Hunskår S, red. Allmennmedisin. Oslo: Gyldendal, 2003: 612-38.

10. Retningslinjer for svangerskapsomsorgen. Oslo: Sosial- og helsedirektoratet, 2005: 105-7.

11. Kass EH, Finland M. Asymptomatic infections of the urinary tract. Trans Assoc Am Physicians 1956; 69: $56-64$

12. Vorland L. Vurdering av bakteriemengde i urin hos kvinner, menn og barn. I: Hovig B, Lassen J, Sandven $\mathrm{P}$ et al, red. Bakteriologisk diagnostikk ved urinveisinfeksjon. Konsensusrapport nr. 7. Oslo: Statens institutt for folkehelse, 1994: 38-40.

13. Digranes A. Vurdering av bakteriemengde i urin hos kvinner, menn og barn. I: Grude N, Hermansen NO, Leegaard T, red. Bakteriologisk diagnostikk ved urinveisinfeksjoner. Strategimøte nr. 21, 2007. Oslo: Nasjonalt folkehelseinstitutt, 2008: $35-42$.

14. Palmqvist E, Aspevall O, Burman E et al. Difficulties for primary health care staff in interpreting bacterial findings on a device for simplified urinary culture. Scand J Clin Lab Invest 2008; 68: 312-6.

15. Bjelkarøy WI, Sandberg S, Thue G et al. Vurdering av urindyppekultur i primærhelsetjenesten. Tidsskr Nor Lægeforen 2006; 126: 149-52.

16. Grude N, Tveten Y, Jenkins A et al. Uncomplicated urinary tract infections. Bacterial findings and efficacy of empirical antibacterial treatment. Scand J Prim Health Care 2005: 23: 115-9.

17. Ferry S, Burman LG, Holm SE. Clinical and bacteriological effects of therapy of urinary tract infection in primary health care: relation to in vitro sensitivity testing. Scand J Infect Dis 1988; 20: 535-44.

18. Kolstrup N, Vold C, Melbye H. Asymptomatisk bakteriuri hos gravide. Tidsskr Nor Lægeforen 2003; 123: 2007.

Manuskriptet ble mottatt 19.5. 2009 og godkjent 17.12. 2009. Medisinsk redaktør Are Brean. 